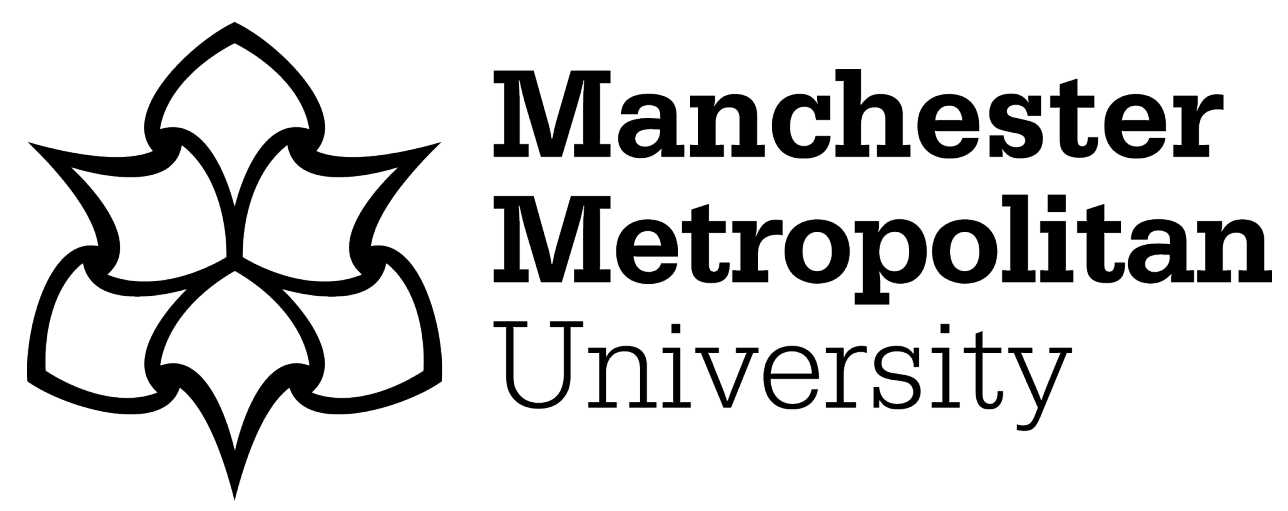

Parnell, D, Millward, P and Spracklen, K (2015) Sport and austerity in the UK: an insight into Liverpool 2014. Journal of Policy Research in Tourism, Leisure and Events, 7 (2). pp. 200-203. ISSN 1940-7963

Downloaded from: https://e-space.mmu.ac.uk/620592/

Publisher: Taylor \& Francis

DOI: https://doi.org/10.1080/19407963.2014.968309

Please cite the published version 
CONTEMPORARY POLICY DEBATE submission for JPRTLE:

\section{Sport and austerity in the UK: An insight into Liverpool 2014}

Daniel Parnell ${ }^{1}$, Peter Millward ${ }^{2}$, Karl Spracklen ${ }^{1}$.

1 Research Institute of Sport, Physical Activity and Leisure, Carnegie Faculty, Leeds Metropolitan University, Leeds, UK

${ }^{2}$ School of Humanities and Social Science, Liverpool John Moores University, Liverpool, UK.

The UK’s Comprehensive Spending Review (CSR) in 2010, outlined $£ 81$ billion of cuts across government departments by 2014/15. The Conservative-Liberal Democrat reform was premised on the 'Big Society' making up for their austere cuts to the state. In this piece, we debate the impact of this on sports development, taking the case study of inner city Liverpool. This example is marked because, on the one hand, it presents cuts to municipal sports facilities which are threatened with closure as a result of shrinking local authority budgets, and on the other this role is partially taken on by an offshoot of Everton Football Club (EFC). The points we debate are: 1) is the change in responsibility from the local authority to a private enterprise, staffed by volunteers, a new turn in sport policy?; and 2) what are the consequences of this on grassroots sport participation?

\section{Austerity in Action}

The austerity measures ushered in by 2010's CSR are not just meaningless figures on a balance sheet or cuts to abstract places that exist 'somewhere'. Rather, cuts on public spending imposed by such measures have unintended consequences on real people and places. The administrative district of Liverpool City Council is one such area, encompassing areas such as Norris Green, Toxteth, Dingle, Everton, Vauxhall, Speke and Anfield, where the city council is attempting to find savings from the sport and recreation service of $£ 10.5 \mathrm{~m}$ over the next three years, with $£ 6.5 \mathrm{~m}$ of that sum having to be made in the first 12 months of that period (Weston, 2014). Such austerity measures are said to hit the poorest communities hardest and the 2010 indices of multiple deprivation classified the area as amongst the most deprived in England. It also has fewer than the English average of physically active adults and more than the English average of obese children (Public Health England, 2013). Indeed, these figures are accentuated in the Dingle (in particular) where it is claimed that three out of four children are 'obese' (Sammons, 2014). 
As a result of this, two of the local authority, council-funded 'Lifestyle' municipal sports facilities - Everton Park Sports Centre, in the deprived 'Liverpool 5' area of the city, and the Dingle's Park Road swimming pool - were threatened with closure. A third, the Austin Rawlinson centre in Speke, had radical changes to its opening hours imposed upon it. Weston (2014) reports that the three centres were chosen because of their high operating and maintenance costs, which contributed to a budgetary deficit of $£ 7.3 \mathrm{~m}$ in the year 2013/14, as Councillor Steve Munby testifies with respect to the Park Road facility:

Park Road baths is a part of Liverpool's history. The challenge is to see if it has a future. A number of things make it special and attractive for certain groups - the small size, the steps, the easy access from cubicles. At the same time it's horribly expensive to run. At last night's meeting we got a clear commitment to look at a community transfer. The challenge now is to try to find a way to make it work. The building needs investment and given its history the obvious organisation to approach is the Heritage Lottery Fund. We need to find ways to cut the cost of water loss, heating and promote greater use. If we can put together a working proposal for community transfer I think it's likely the building would still have to close for a period to allow repairs. There's a lot to do if the baths are to be saved but as councillors we're committed to working with user groups to try to put together something that works.

Councillor Steve Munby (quoted in Sammons 2014)

Aronowitz (2003) suggests that is the more traditional 'middle classes' that pursue the actions of civil society such as volunteering, activism and forming campaign groups, yet in these parts of Liverpool local residents have also mobilised to resist such changes. Campaigners in the Dingle area of the city have suggested that under the current proposals, they would have to travel on two buses to the city council's flagship 'Aquatics Centre' in the Wavertree district of the city to be able to swim, and that would cost a family of five $£ 10$ in transport costs alongside other time commitments (Sammons 2014). As a result of these now unsatisfactory provisions local campaigner, Lucy Dossor said that:

We asked the council to collaborate with us on a working party to discuss options and possible ways forward for the threatened services. They kept saying how keen they were to work with the community and user groups, so now we must take them at their word and push for some detailed discussions about other income streams and community takeover options.

Campaigner Lucy Dossor (quoted in Sammons 2014)

Indeed, alternative revenue streams and the potential transfer of the facilities into 'community ownership' reduce the 'financial burden' of promoting sport participation and 
physical activity to local populations in a socially deprived part of the country, and particularly poor areas in that city. Thus, the pathway of the transfer of provisions for public health begins to move - in an era of dwindling state resources - toward something that might be called 'the Big Society'. With reducing local council budgets, the answers to public problems do not come from the state but from community groups and, potentially, private enterprise groups as we now discuss.

Changing Responsibilities for Sport Development: from the Local Authority to a Private Enterprise

Everton Football Club (EFC) is a private enterprise that exists in the neo-liberalised conditions of the Premier League and is geographically rooted within the deprived 'Everton district' area of Liverpool (Millward, 2011). It is also simultaneously a 'local', 'national' and 'global' brand (Millward, 2011) and, related to this, one of the reputed leaders in community engagement (Everton, 2014). EFC runs Everton in the Community (EitC), the community arm and registered charity of the football club. Everton is one of the 20 English Premier League and 72 English Football League Clubs that operate an outward facing community engagement arm (Anagnostopoulos and Shilbury, 2013). That work is broadly carried out across social welfare issues including health, education and inclusion (Parnell et al., 2013; Parnell and Richardson, 2014). Whilst many local community groups struggle to survive through diversification of activity and over-zealous commissioning embedding unrealistic and unachievable outputs and outcomes (with little hope of any genuine evaluation measures) (Pringle, McKenna and Zwolinksy, 2013), EitC appears to have found a niche for growth (Bingham et al., 2014). Indeed, EitC is not alone, as other professional sport clubs have been commissioned to deliver a range of health improvement interventions, including Stoke City Community Trust and Notts County in the Community. The latter has recently evidenced a $5 \%$ reduction in body weight by both men and women participating in their scheme (Rutherford, et al., 2014), which echoes findings of a randomised control trial (RCT) conducted in Scottish professional football clubs (Hunt et al., 2014). Perhaps, football as a private enterprise can offer a new way forward for something that appears to be an emerging trend.

The closure and changing practices of municipal sport centres is not particular to Liverpool. Rather, these changes are occurring across the country. Private sport centres seem to have changed the tastes of where and how to exercise for many in the UK. A regular 
response has been for local authorities (LAs) to build more modern 'show-piece' sport centres - including gyms, swimming pools and potentially squash/badminton and small sided football facilities - and this, allied to the CSR, has ushered in an era where old facilities have closed. In Liverpool, the Aquatics Centre opens from 7am until 10pm on weekdays and has its facilities in constant use. The facilities are modern and mirror the 'quality' of private health clubs nearby. Such facilities are undoubtedly expensive to run (King, 2014), so in this time of austerity when local authorities are particularly sensitive to cost, this Liverpool model is likely to appeal to councils elsewhere.

\section{Consequences for Grassroots Sport Participation}

Future data from the Sport England Active People Survey will make interesting reading. An analysis of sport participation figures, especially cross-tabulated by social class breakdowns in the LAs which have experienced the most profound changes in the running of municipal sport centres, will be worth watching. Our prediction is that, based upon the rise of private enterprise health promotion activities, like those at EitC, qualitative evidence which shows positive experiences of sport will continue (and perhaps even grow in enthusiasm). Similarly, we predict that qualitative evidence that weighs up the success of flagship LA sport facilities, like Liverpool's Aquatics Centre will show solid evidence of residents enjoying the facilities. The 'cracks in the pavement' might emerge in Active People Survey data if they show that sport participation - especially by those in lower social classes, where car ownership is lower (so people cannot travel or afford to travel to flagship municipal facilities or those offered by private enterprises) - might have fallen in key 'physical activity for public health' areas, such as swimming. This would be a negative, potentially long term, legacy of the CSR, as would the concentration of what is left from the public purse on fewer LA sport centres.

\section{References}

Anagnostopoulos, C. \& Shilbury, D. (2013). Implementing corporate social responsibility in English football: Towards multi-theoretical integration. Sport, Business and Management: An International Journal, 3(4), 268-284.

Aronowitz, S. (2003) How Class Works: Power and Social Movement, New Haven: Yale University Press.

Bingham, D.D., Parnell, D., Curran, K., Jones, R., \& Richrdson, D. (2014). Fit Fans: perspectives of a practitioner and understanding participant health needs within a 
health promotion programme for older men delivered within an English Premier League Football Club, Soccer \& Society, DOI: 10.1080/14660970.2014.920624

Everton Football Club (2014). Everton in the Community. Retrieved June 24, 2014, from http://community.evertonfc.com

Millward, P. (2011). The Global Football League. Palgrave: Basingstoke.

Parnell, D., G. Stratton, B. Drust., \& Richardson, D. (2013). Football in the Community schemes: Exploring the effectiveness of an Intervention in Promoting Positive Healthful Behaviour Change, Soccer and Society, 14, 35-51.

Parnell, D., \& Richardson, D. (2014) Introduction, Soccer and Society, DOI:10.1080/14660970.2014.920619.

Pringle, A., McKenna, J., \& Zwolinsky, Z. (2013). Health improvement and professional football: players on the same side?, Journal of Policy Research in Tourism, Leisure and Events, 5, 2, 207-212, DOI: 10.1080/19407963.2013.798159

Public Health England (2013) Health Profiles 2013. London: Author. Retrieved June 25, 2014 from http://www.apho.org.uk/resource/view.aspx?RID=126453

Sammons, A. (2014) Fight to save Dingle pool gets thumbs up from Beth Tweddle. Liverpool Confidential, Liverpool: Author. Retrieved June 24, 2014, from www.liverpoolconfidential.co.uk/News-and-Comment/Fight-to-save-Dingle-poolgets-thumbs-up-from-Beth-Tweddle

The Association for Public Service Excellence (APSE) (2011). Local authority Sport and Recreation Services in England: Where next?, APSE: Author. Retrieved June 24, 2014, from http://www.apse.org.uk/apse/index.cfm/research/current-researchprogramme/local-authority-sport-and-recreation-services-in-england-wherenext/local-authority-sport-and-recreation-services-in-england-where-next/

Weston, A. (2014). Public's last chance to have their say on leisure centre cuts, The Liverpool Echo, 27 May, 2014. 